\title{
IMPLEMENTASI KEBIJAKAN PENETAPAN PAJAK BUMI DAN BANGUNAN PERDESAAN PERKOTAAN DALAM MENINGKATKAN PENDAPATAN DAERAH DI KOTA SERANG
}

\author{
Eka Afriliyanto Adi ${ }^{1}$, Said Djamaludin ${ }^{1}$, Suhaya ${ }^{1}$ \\ ${ }^{1}$ Pascasarjana UNIS-Tangerang \\ Email: suhaya@unis.ac.id
}

\begin{abstract}
Abstrak
Penelitian ini dilatarbelakangi fenomena bahwa Pajak Bumi dan Bangunan berpotensi meningkatkan Pendapatan Asli Daerah, pengelolaan pajak tersebut hanya belum maksimal. Penelitian ini bertujuan untuk menganalisis implementasi kebijakan penetapan Pajak Bumi dan Bangunan dalam meningkatkan pendapatan daerah di Kota Serang, serta mengetahui faktor penghambat dan pendukung yang dapat meningkatkan pendapatan daerah di Kota Serang Tipe penelitian yang dipergunakan adalah kualitatif. Dasar penelitian yang digunakan adalah metode survey. Pengumpulan data dilakukan menggunakan teknik observasi, wawancara dan studi literatur. Data dikumpulkan dari berbagai sumber hingga didapatkan data yang cukup. Data yang diperoleh selanjutnya dianalisis secara kualitatif melalui pengorganisasian data, menjabarkannya kedalam unit-unit, menyusun kedalam pola, memilih mana yang penting dan yang akan dipelajari, menguraikan dalam bentuk kata dan kalimat, dan selanjutnya membuat kesimpulan. Hasil penelitian menunjukan bahwa komunikasi, sumber daya manusia, disposisi/sikap dan struktur birokrasi memiliki pengaruh terhadap pengelolaan pajak bumi dan bangunan dalam meningkatkan pendapatan daerah di Kota Serang.
\end{abstract}

Kata Kunci : Implementasi, Pajak Bumi dan Bangunan, Pendapatan Asli Daerah

\section{A. Pendahuluan}

Pemerintah Kota Serang memiliki target pendapatan asli daerah lebih tinggi setiap tahunnya untuk pembangunan. berdasarkan Undang-Undang Nomor 33 Tahun 2004 tentang Perimbangan keuangan Antara Pusat dan Daerah Pasal 1 angka 18 bahwa Pendapatan asli daerah, selanjutnya disebut PAD adalah pendapatan yang diperoleh daerah yang dipungut berdasarkan peraturan daerah sesuai dengan peraturan perundangundangan. Pendapatan asli daerah Kota Serang sendiri di hasilkan dari pajak property (PBB), pajak kendaraan bermotor, pajak penghasilan dan pajak jasa umum seperti pajak hiburan. PBB-P2 yang merupakan pajak atas bumi dan/ atau bangunan dimiliki, dikuasai, dan dimanfaatkan oleh orang pribadi atau badan kecuali kawasan yang digunakan untuk kegiatan usaha perkebunan, perhutanan dan pertambangan. Penerimaan PBB-P2, memiliki konstribusi yang cukup signifikan terhadap perolehan Pendapatan Asli Daerah (PAD) di Kota Serang. PBB-P2 mulai berlaku secara efektif di Kota Serang pada tanggal 1 Januari 2014 dan terhitung sejak tanggal 1 Januari 2015 pembayaran PBB-P2 sudah dialihkan ke pihak Bank Jabar Banten (BJB).

Dengan adanya pelimpahan wewenang tersebut pemerintah daerah berusaha membuat kebijakan-kebijakan untuk mencapai target yang ditetapkan 
pemerintah pusat kepada masing-masing pemerintah daerah. Kebijakan yang ditetapkan pemerintah daerah antara lain adalah menetapkan target-target yang harus dicapai oleh daerah di tingkat bawahnya, sampai dengan tingkat desa/kelurahan. Dimana pemungutan di tingkat desa/kelurahan merupakan ujung tombak dari kegiatan pemungutan PBBP2 secara keseluruhan, karena di tingkat desa/kelurahan para petugas pemungut akan berhadapan langsung dengan masyarakat wajib pajak.

Berdasarkan Peraturan Daerah Kota Serang Nomor 17 Tahun 2010 tentang Pajak Daerah, bahwa terdapat jenis-jenis Pajak Daerah di Kota Serang yaitu Pajak Hotel, Pajak Restoran, Pajak Hiburan, Pajak Reklame, Pajak Penerangan Jalan, Pajak Mineral Bukan Logam dan Batuan, Pajak Parkir, Pajak Air Tanah, Pajak Sarang Burung Walet, Pajak PBB-P2, dan BPHTB.

Dalam pengalihan PBB-P2, persiapan yang dilakukan oleh pemerintah daerah Kota Serang adalah dengan mengesahkan Peraturan Daerah Nomor 9 tahun 2013 tentang Pajak Bumi dan Bangunan sektor Perdesaan dan Perkotaan (PBB-P2), Peraturan Walikota dan Standar Operasional Prosedur (SOP) yang berkaitan dengan PBB-P2 , sarana dan prasarana penunjang, serta dibentuknya Unit Pelaksana Teknis (UPT) PBB-P2 di dua kecamatan yakni UPT kecamatan Serang dan UPT Kecamatan Cipocok Jaya (Arbaiyah,

\section{B. Metode Penelitian Jenis Penelitian}

Metode penelitian yang akan digunakan dalam penelitian ini adalah penelitian kualitatif deskriptif. Peneliti menggunakan pendekatan penelitian ini
2016:6).

Melihat fenomena yang terjadi
bahwa PBB-P2 berpotensi dalam meningkatkan PAD, pengelolaan pajak tersebut hanya belum maksimal. Dalam hal ini dinas pendapatan daerah memiliki wewenang dalam pengelolaan Pajak daerah dalam meningkatkan pendapatan asli daerah, Proses pemungutan dan hasilnya sangat berpengaruh pada kesadaran wajib pajak dalam membayar dan melunasi pajak terutangnya secara tepat waktu atau sebelum jatuh tempo serta kinerja pemerintah yang bersangkutan dalam hal pemungutan pajak sangatlah berperan pentingdalam peningkatan PAD.

\section{Fokus Penelitian}

1. Apakah implementasi kebijakan penetapan pajak bumi dan bangunan perdesaan dan perkotaan dalam meningkatkan pendapatan daerah di kota Serang ?

2. Apa saja faktor Pendukung pada implementasi kebijakan penetapan pajak bumi dan bangunan perdesaan dan perkotaan dalam meningkatkan pendapatan daerah di kota Serang?

3. Apa saja faktor Penghambat pada implementasi kebijakan penetapan pajak bumi dan bangunan perdesaan dan perkotaan dalam meningkatkan pendapatan daerah di kota Serang?

karena sesuai dengan jenis penelitian yang akan dilakukan, yaitu untuk menganalisis implementasi kebijakan penetapan PBB dalam meningkatkan pendapatan daerah di kota Serang. 


\section{Fokus Penelitian}

Fokus penelitian diperlukan untuk mempersempit objek penelitian yang akan diteliti. Adanya fokus penelitian meliputi aspek :

1. Implementasi kebijakan penetapan PBB-P2 di kota Serang meliputi aspek

- Komunikasi

- Sumber daya manusia

- Disposisi atau sikap

- Struktur birokrasi

2. Peningkatan Pendapatan daerah di kota Serang meliputi aspek :

- Hasil pajak daerah

- Retribusi

3. Implementasi kebijakan penetapan PBB-P2 kaitannya dengan peningkatan pendapatan di kota Serang

- Kepatuhan dalam pengadminitrasian pajak $\mathrm{PBB}$

- Kewenangan dinas pendapatan kota Serang dalam pemungutan pajak

\section{Proses Pengumpulan Data}

Pengumpulan data yang dilakukan dalam penelitian ini meliputi tahap-tahap sebagai berikut:

\section{Memasuki lokasi penelitian}

Sebelum melakukan penelitian, peneliti telah melakukan pra-riset yang dimaksudkan untuk mengetahui bagaimana kondisi lokasi penelitian. Sehingga ketika proses penelitian, Pegawai Dinas Pengelolaan Keuangan Daerah telah mengetahui maksud dan tujuan peneliti melakukan penelitian di kantor tersebut. Ketika memasuki lokasi penelitian, peneliti telah membawa surat legal dari Fakultas Ilmu Administrasi Universitas Islam Syekh-Yusuf Tangerang supaya dapat meminta data yang dibutuhkan dalam proses penelitian.

2. Ketika berada di lokasi penelitian

Setelah membuat janji pertemuan untuk wawancara, peneliti mencari berbagai informasi yang dibutuhkan dalam penelitian ini seperti dokumen hasil penerimaan Pajak Bumi dan Bangunan di Dinas Pengelolaan Keuangan Daerah Kota Serang.

3. Teknik Pengumpulan Data

Peneliti mengumpulkan data sesuai dengan fokus penelitian yang telah ditetapkan sebelumnya. Proses pengumpulan data yang telah dilakukan oleh peneliti adalah sebagai berikut:

a. Wawancara Mendalam

Wawancara yang dilakukan oleh peneliti di Dinas Pengelolaan Keuangan Daerah Kota Serang. Teknik ini dilakukan dengan cara face to face, sehingga pewawancara dapat mengetahui bagaimana kondisi dan situasinya. Dalam melakukan wawancara mendalam pada informan yang terkait, peneliti mengajukan pertanyaan-pertanyaan yang sesuai dengan batasan masalah yang telah ditetapkan sebelumnya kepada informan yang berkaitan dengan Implementasi Kebijakan Penetapan PBB Dalam Meningkatan Pendapatan Daerah Di Kota Serang.

4. Observasi

Observasi merupakan teknik yang digunakan dalam melakukan pengumpulan data dengan pengamatan secara langsung terhadap objek penelitian. Menurut Nasution (1998) dalam Sugiyono, 2009:226) observasi merupakan fakta dari semua ilmu pengetahuan. Seorang peneliti harus 
bisa melihat apa yang sebenarnya terjadi dilapangan disamping melihat data yang ada, sehingga peneliti mampu melihat bagaimana kenyataan yang ada. Observasi di Dinas Pengelolaan Keuangan Daerah Kota Serang.

5. Dokumentasi

Dokumen merupakan sumber data yang dapat berupa catatan peristiwa yang telah berlalu. Hal ini sesuai dengan yang disampaikan oleh Sugiyono (2012:240) bahwa dokumentasi merupakan suatu teknik mengumpulkan data yang berbentuk tulisan, gambar atau karya-karya monumental dari seseorang. Dokumen yang berbentuk tulisan misalnya catatan harian, sejarah kehidupan, cerita, biografi, peraturan dan kebijakan. Dokumen yang berbentuk gambar misalnya foto, gambar hidup, sketsa dan lain-lain. Metode dokumentasi digunakan sebagai pelengkap dari dua metode yang penulis lakukan di atas. Teknik penelitian yang diperoleh dari dokumen-dokumen serta arsip-arsip Dinas Pengelolaan Keuangan Daerah Kota Serang yang ada hubungannya dengan masalah pajak bumi dan bangunan.

\section{Analisa Data Penelitian}

Sesuai dengan teknik pengumpulan data yang telah peneliti lakukan yaitu wawancara, dokumentasi dan observasi, maka hasil data yang diperoleh dari proses wawancara, dokumentasi dan observasi itu diolah dengan cara :

1. Invetarisasi data.
2. Penyeleksian data sesuai dengan tujuan penulisan dan permasalahan yang akan diteliti oleh peneliti.

3. Menyusun data

Teknik analisis data yang dilakukan dalam penelitian ini adalah teknik analisa kualitatif, peneliti menganalisis data dengan cara menjelaskan dengan bentuk yang logis. Menurut Sugiyono (2012:244) teknik analisis data merupakan proses mencari dan menyusun secara sistematis data yang telah diperoleh melalui wawancara, catatan lapangan, dan dokumentasi dengan cara mengorganisasikan data kedalam kategori, menjabarkan ke dalam unit-unit,melakukan sintesa, menyusun kedalam pola, memilih mana yang penting dan yang akan dipelajari dan membuat kesimpulan sehingga mudah difahami oleh diri sendiri dan orang lain. Teknik analisis data yang akan digunakan dalam penelitian ini adalah dengan menggunakan model analisis seperti yang telah diberikan oleh Miles dan Huberman (Sugiyono, 2012:246), yaitu :

1. Reduksi Data

2. Penyajian Data

3. Verifikasi Data dan Menarik Kesimpulan

\section{Keabsahan Data}

Menentukan validitas data dalam penelitian kualitatif memerlukan kriteria

untuk memperoleh tingkat kepercayaan penemuan. Hal ini serupa dengan yang dinyatakan oleh Sugiyono (2010:117) bahwa validitas data merupakan derajat ketepatan antara data yang terjadi pada objek penelitian dengan data yang dapat dilapor kan oleh peneliti. Oleh sebab itu, penyajian data terkait dengan apa yang 
terjadi sebenarnya dengan apa yang peneliti berikan akan menjadi salah satu ukuran validitas data tersebut. Guna menjamin validitas data yang dikumpulkan dalam penelitian ini maka teknik yang digunakan adalah teknik triangulasi. Teknik triangulasi merupakan teknik pemeriksaan keabsahan data yang memanfaatkan sesuatu yang diluar data itu untuk keperluan perbandingan terhadap data itu (Moleong 1998 :78). Triangulasi yang digunakan dalam penelitian ini adalah triangulasi sumber yaitu dengan membandingkan antara sumber yang diperoleh dan hasil wawancara satu informan dengan informan yang lain dalam satu masalah agar di dapat simpulan yang obyektif.

\section{Hasil Penelitian Dan Pembahasan}

Pembahasan hasil penelitian merupakan penapsiran terhadap hasil akhir dalam melakukan pengujian data dengan teori dan konsep para ahli. Adapun pembahasan terkait dengan implementasi Kebijakan Penetapan Pajak Bumi dan Bangunan Perdesaan dan Perkotaan Dalam Meningkatkan Pendapatan daerah, adalah sebagai berikut :

\section{Komunikasi dalam Implementasi Kebijakan Penetapan Pajak Bumi dan Bangunan Perdesaan dan Perkotaan Dalam Meningkatkan Pendapatan Daerah}

Komunikasi

memberikan

informasi kesemua pihak yang terkait dengan program yang akan dilakukan, kesalahan dalam memahami informasi akan mengakibatkan perbedaan presepsi, sehingga menimbulkan perbedaan dalam implementasi kebijakan, dalam pelaksanaan Kebijakan Penetapan Pajak Bumi dan Bangunan Perdesaan dan Perkotaan Dalam Meningkatkan Pendapatan daerah tahapan komunikasi merupakan yang pertama dilakukan untuk untuk memberikan informasi kepada semua pihak yang terkait. Masyarakat sebagai salah satu unsur yang terkait langsung dengan Penetapan Pajak Bumi dan Bangunan Perdesaan dan Perkotaan Dalam Meningkatkan Pendapatan daerah dan merupakan target dari implementasi kebijakan berhak untuk mendapatkan informasi yang lengkap mengenai kebijakan.

Menurut Edward III dalam Agustino, perintah yang diberikan dalam pelaksanaan suatu komunikasi harus konsisten dan jelas untuk ditetapkan atau dijalankan. Jika perintah yang diberikan sering berubah-ubah, maka dapat menimbulkan kebingungan bagi pelaksana di lapangan dan juga bagi masyarakat yang melaksanakan kebijakan tersebut. Oleh karena itu konsistensi juga harus mendapat perhatian dalam sebuah komunikasi.

Transmisi merupakan faktor utama dalam hal komunikasi pelaksana kebijakan. Menurut Agustino, penyaluran komunikasi yang baik akan menghasilkan suatu implementasi yang baik pula.

Sesuai dengan pendapat Edwars III dalam Winarno (2014: 179) bahwasanya: "Ada beberapa hambatan yang timbul mentramisikan perintah-perintah implementasi, pertama, pertentangan pendapat antara para pelaksana dengan perintah yang dikeluarkan oleh pengambil kebijakan, kedua informasi melewati berlapis-lapis hierarki birokrasi, ketiga, penangkapan komunikasi-komunikasi mungkin dihambat oleh presepsi yang selektif dan ketidakmampuan pada persyaratan-persyaratan suatu kebijakan”. 
Wawancara di atas menunjukkan bahwa komunikasi belum terbangun dengan baik, mengingat belum optimalnya pelaksanaan sosialisasi baik di dalam instansi Dinas Pengelola keuangan Daerah Kota Serang sendiri, maupun sosialisasi ke masyarakat sebagai target kebijakan, kebijakanpun masih belum menyeluruh dan berpotensi dipahami berbeda oleh masyarakat.

Sumberdaya dalam Implementasi Kebijakan Penetapan Pajak Bumi dan Bangunan Perdesaan dan Perkotaan Dalam Meningkatkan Pendapatan daerah

Wawancara di atas menunjukkan bahwa sumberdaya belum tersedia dengan maksimal, dimana kurangnya dukungan staf baik dari segi jumlah dan kemampuan, belum adanya petunjuk pelaksanaan dan petujuk teknis dalam pelaksanaan kebijakan, serta minimnya dukungan peralatan dan kewenangan dalam pengelolaan anggaran.

Berdasarkan data tyang telah disampaikan diatas, Staf yang memadai serta keahlian-keahlian yang baik untuk melaksanakan pelayanan publik, jumlah yang banyak tidak secara otomatis mendorong implementasi berhasil. Kurangnya kecakapan yang dimilki oleh para pegawai pemerintah ataupun staf, namun disisi lain kekurangan staf juga akan menimbulkan persoalan yang pelik menyangkut implementasi kebijakan yang efektif. Menurut hasil pengamatan peneliti dilapangan sumberdaya personil dan non personil mempunyai peran penting di dalam proses implementasi kebijakan. Staf merupakan salah satu bagian yang ada di dalam organisasi yang mempunyai peran peting dalam membantu mensukseskan setiap kegiatan.
Untuk itu, Conyers (1990) menegaskan bahwa: "Harus realistis dalam hal sumberdaya yang ada untuk implementasi guna mendukung tercapainya suatu rencana". Dengan demikian sumberdaya menjadi sangat penting.

Edward III dalam Widodo (2010:101) menyimpulkan bahwa terbatasnya sumberdaya akan mempengaruhi keberhasilan pelaksanaan kebijakan. Disamping program tidak bisa dilaksanakan dengan optimal, keterbatasan anggaran menyebabkan disposisi para pelaku kebijakan rendah. Setiap program yang dijalankan sangat memerlukan dukungan anggaran maupun staf dalam melaksanakan suatu pekerjaan dan memonitoring program kesemuanya itu membutuhkan biaya selanjutnya Seperti apa yang diungkapkan oleh Widodo (2012:100) terbatasnya anggaran yang tersedia menyebabkan kualitas pelayanan pada publik yang harus diberikan kepada masyarakat juga terbatas.

\section{Disposisi dalam Implementasi Kebijakan Penetapan Pajak Bumi dan Bangunan Perdesaan dan Perkotaan Dalam Meningkatkan Pendapatan daerah}

Dampak dari adanya kekuataan sering mengesampingkan pelaksanaan kebijakan yang diitetapkan oleh pembuat kebijakan. Sehingga pelaksanaannya akan cenderung adanya suatu kepentingan organisasi sebagai prioritas mereka. Hal ini pula yang menyebabkan perbedaaan pandangan dan pemikiran dalam pembuat keputusan yang pada akhirnya mendorong ketidaksempurnaan pelaksanan kebijakan tersebut. Badanbadan ataupun lembaga mempunyai 
pandangan berbeda terkait dengan kebijakan yang akan dicapai akan menghalangi adanya kerjasama dan menghambat proses implementasi itu sendiri. Komitmen-komitmen yang berbeda akan menimbulkan suatu perbedaan diantara banyak personil yang memegang tanggung jawab program yang akan dijalankan. Kepentingan badan atau organisasi memungkinkan menciptakan adanya kerjasama yang gagal serta memboroskan sumber-sumber yang ada karena disebabkan pertentangan dimasing-masing pihak.

Perilaku ini terbangun oleh pengalaman yang mereka rasakan bahwa pemerintah lebih cenderung memmanfaatkan masyarakat untuk kepentingannya institusi, hal ini menurut Edward III dalam Tachjan (2006:83) mengungkapkan bahwa Disposisi faktor yang bertalian dengan watak atau sikap serta komitmen yang harus dimiliki oleh pelaksana kebijakan. Pelaksana tidak hanya harus tahu dikerjakan dan memiliki kapasitas untuk melakukannya, melainkan juga mesti memiliki kehendak/sikap untuk melakukan kebijakan. Peran Pemerintah dalam implementasi kebijakan Kebijakan Penetapan Pajak Bumi dan Bangunan Perdesaan dan Perkotaan Dalam Meningkatkan Pendapatan daerah lebih cenderung kepada kepentingan.

\section{Struktur Birokrasi dalam Implementasi Kebijakan Penetapan Pajak Bumi dan Bangunan Perdesaan dan Perkotaan Dalam Meningkatkan Pendapatan daerah}

Birokrasi merupakan salah satu yang paling sering bahkan secara keseluruhan menjadi pelaksana kebijakan. Birokrasi merupakan organisasi yang memiliki bentuk-bentuk organisasi untuk melakukan kesepakatan kolektif, untuk memecahkan masalah-masalah sosial dalam kehidupan moderen. Birokrasi tidak hanya berada dalam struktur pemerintah saja, akan tetapi organisasi swasta memiliki sistem birokrasi, dimana birokrasi tersebut sengaja dibuat untuk menjalankan seuatu kebijakan tertentu.

Sesuai dengan pendapat tersebut birokrasi di Kota Serang merupakan lembaga yang sulit untuk netral, kepentingan-kepentingan golongan, pribadi masih mendominasi implementasi kebijakan. Peran birokrasi dalam menjalankan peran dalam proses birokrasi dalam implementasi kebijakan publik, maka struktur birokrasi sangat urgen di dalam implementasi kebijakan publik.

Faktor Pendukung yang Mempengaruhi Kebijakan Penetapan Pajak Bumi dan Bangunan Perdesaan dan Perkotaan Dalam Meningkatkan Pendapatan daerah

Berdasarkan hasil temuan melalui wawancara penelitian dalam kaitannya dengan pelaksanaan kebijakan penataan ruang dalam pengendalian pemanfaatan ruang terdapat beberapa pendukung dalam pelaksanaannya, yaitu:

1. Penyusunan kebijakan penetapan pajak bumi dan bangunan perdesaan dan perkotaan sudah dilaksanakan, sehingga telah tersedianya dokumen kebijakan yang dijadikan arahan dalam pemanfaatan

2. Faktor pendukung implementasi kebijakan penetapan pajak bumi dan bangunan perdesaan dan perkotaan dalam meningkatkan pendapatan daerah di kota Serang dapat dilihat dari: 
3. Komunikasi penyebaran informasi telah dilaksanakan walaupun sifatnya satu arah yaitu melalui web, sosialisasi dan berupa spanduk

4. Sumberdaya yang berkaitan dengan implementasi kebijakan penetapan pajak bumi dan bangunan perdesaan dan perkotaan dalam meningkatkan pendapatan daerah di kota Serang dilihat dari jumlah pegawainya memang belum mencukupi, tetapi bila dilihat dari latarbelakang keilmuan dan pengalaman pada Bidang pajak bumi dan bangunan, jumlah staf yang ada dapat menjadi faktor pendukung berjalannya implementasi kebijakan pajak bumi dan bangunan dengan baik.

5. Pembagian tanggungjawab pada masing-masing unit kerja, baik pada unit lain di luar dinas atau dari pemerintah daerah sendiri, maupun unit-unit yang berada dalam lingkungan Dinas Pengelola Keuangan Daerah di Kota Serang dalam pajak bumi dan bangunan sudah jelas, sehingga tidak terjadi distorsi kepentingan dan tanggung jawab.

\section{Faktor Penghambat yang Mempengaruhi Implementasi Kebijakan Penetapan Pajak Bumi dan Bangunan Perdesaan dan Perkotaan Dalam Meningkatkan Pendapatan daerah}

Berdasarkan data penelitian yang dianalisa, maka diidentifikasi faktor penghambat implementasi kebijakan penataan ruang dalam pengendalian pemanfaatan ruang adalah :

1. Informasi

Minimnya informasi baik ditingkat implementator maupun di masyarakat mengakibatkan tidak meratanya pemahaman pelaksana kebijakan dan tingkat kepedulian masyarakat sebagai obyek kebijakan dalam memaknai kebijakan.

2. Isi Kebijakan

Masih belum terperincinya sasaran dalam penetapan prioritas program, isi program yang dibuat belum mengedukasi masyarakat untuk mematuhi aturan yang ada. Hal ini dapat dilihat dari bentuk komunikasi yang satu arah, tidak adanya alat peraga dalam sosialisasi, isi kebijakan yang tidak dapat dimengerti semua lapisan masyarakat, serta dukungan sumberdaya yang terbatas, baik sumberdaya manusia maupun anggaran bagi pelaksanaan program.

3. Dukungan

Belum adanya sinergi dari semua lapisan birokrasi baik dari Pihak-pihak yang berkaitan

4. Pembagian Potensi

Belum adanya pembagian peran dan fungsi yang jelas mengenai kewenangan dalam pelaksanaan kebijakan di lapangan.

5. Adanya konsep ketidakpatuhan selektif terhadap hukum,

Suatu kebijakan publik akan menjadi efektif apabila dilaksanakan dan mempunyai manfaat positif bagi anggotaanggota masyarakat. Dengan kata lain, tindakan atau perbuatan manusia sabagai anggota masyarakat harus sesuai dengan apa yang diinginkan oleh pemerintah atau Negara. Sehingga apabila perilaku atau perbuatan mereka tidak sesuai dengan keinginan pemerintah atau Negara, maka suatu kebijakan publik tidaklah efektif. 


\section{Kesimpulan Dan Saran}

\section{Kesimpulan}

Berdasarkan hasil penelitian dan hasil pembahasan yang dilakukan pada bab sebelumnya, maka peneliti dapat menarik beberapa kesimpulan sebagai berikut :

1. Implementasi Kebijakan Penetapan PBB-P2, Kebijakan penetapan PBB-P2 di Kota Serang belum efektif, diisebabkan oleh a). aspek komunikasi yang belum maksimal, dikarenakan tingkat kesadaran masyarakat yang minim, sehingga target yang diitietapkan oleh Dinas Pengelola Keuangan Daerah Kota Serang belum sesuai dengan target. b). aspek sumberdaya, diilihat dari jumlah staf yang masih minim, sehingga proses melakukan kebiijakan masih minim, selain itu tidak ditunjangnya latar belakang pendidikan yang spesifik pada staf dan tidak adanya pelatihan khusus atau diklat dalam kebijakan PBB-P2. c). belum terciptanya sikap baik antara petugas dengan masyarakat dalam memberikan sosialisasi tentang kebijakan PBB-P2. d). aspek struktur birokrasi belum tercapainya komunikasi petugas dengan petugas lainnya

2. Anggaran Pendapatan Daerah yang direalisasikan belum mencapai target, dikarenakan kurang maksimalnya dalam mempertahankan nilai pendapatan asli daerah, masih jauh dari target yang sudah ditetapkan. Permasalahan utama pada pendapatan daerah pada dasarnya adalah masih terdapat pada tingginya ketergantungan sumber pendapatan daerah kepada pemerintah pusat. Selain karena keterbatasan pendapatan asli daerah, lainnya adalah belum optimalnya pengelolaan

3. Dalam Undang-Undang Pajak Bumi dan Bangunan maupun peraturanperaturan turunannya tidak mengatur rewards bagi wajib pajak yang telah membayar pajak dengan baik. Pemerintah daerah sebagai pihak yang berkepentingan untuk mendapatkan pemasukan dari sektor PBB telah berusaha memberikan penghargaan kepada wajib pajak maupun institusi pemungut di lapangan yang telah mendukung keberhasilan pemungutan PBB. Di kota Serang, rewards atau bentuk penghargaan yang diberikan kepada wajib pajak yang telah membayar pajak lebih awal diberikan dalam bentuk pemberian hadiah undian bagi Wajib pajak yang telah melunasi PBB sebelum bulan agustus setiap tahunnya. Adanya Penghargaan bagi yang berprestasi atau yang kooperatif tentunya juga perlu dibarengi dengan adanya hukuman atau punishment bagi yang melanggar. Dalam Kebijakan PBB telah memuat sanksi terhadap para pelanggar kebijakan ini Sanksi yang diatur hanyalah sanksi denda atas keterlambatan pembayaran yang besarnya ditetapkan sebesar $2 \%$ per bulan keterlambatan dari ketetapan pajak yang telah ditentukan, terhadap pelanggaran-pelanggaran tersebut dapat dikenai sanksi pidana kurungan paling lama satu tahun atau denda paling tinggi Rp. 2.000.000,- (dua juta rupiah).

\section{Saran}

Berdasarkan kesimpulan diatas penulis menyampaikan saran sebagai berikut :

$\begin{array}{llr}\text { 1. Disarankan } & \text { agar pemerintah } \\ \text { memperhatikan } & \text { mengenai kebijakan }\end{array}$ 
pengelolaan Pajak Bumi dan Bangunan yang selama ini dilakukan sehingga akan dapat meningkatkan penerimaan pajak Pajak Bumi dan Bangunan.

2. Disarankan agar peningkatan koordinasi lintas sektoral antara Dinas Pendapatan, Kantor Pajak Bumi dan Bangunan, Kecamamatan, dan Desa.

3. Disarankan untuk meningkatkan efektitvitas penerimaan Pajak Bumi dan Bangunan, maka sebaiknya pemerintah lebih meningkatkan sarana dan prasarana kantor sebagai penunjang aktivitas pekerjaan, selain itu melakukan pembinaan kepada kolektor serta melakukan pemberian sanksi kepada wajib pajak mengenai pentingnya Pajak Bumi dan Bangunan, karena dengan adanya Pajak Bumi dan Bangunan maka akan digunakan untuk membiayai pembangunan daerah.

\section{Daftar Pustaka}

Abut, H. 2007.Perpajakan.Buku Satu.Jakarta: Diadit Media.

Agustino, L. 2008. Dasar-Dasar Kebijakan Publik.Bandung: Alfabeta.

Andi Tenri Ummu .2015. Implementasi Kebijakan Pengelolaan Pajak Bumi Dan Bangunan (Pbb) Di Kecamatan Ulaweng Kabupaten Bone. Skripsi. Makasar: Universitas Hasanuddin.

Arbaiyah. 2016. "Kinerja Pelayanan Pajak Bumi dan Bangunan Perdesaan dan Perkotaan (PBB-P2) di Unit Pelaksana Teknis Pajak Bumi dan Bangunan Perdesaan dan Perkotaan (UPT PBB-P2) Kecamatan Serang Kota Serang”. Skirpsi. Serang: Universitas Sultan Ageng Tirtayasa.

Arikunto, S, 2013. Prosedur Penelitian Suatu Pendekatan Praktik. Jakarta: Rineka Cipta.

Arisman,S. 2015. Analisis Pengelolaan Pajak Bumi Dan Bangunan Dalam Meningkatkan Pendapatan Asli Daerah Di Kabupaten Takalar. Skripsi. Makasar: Universitas Hasanuddin.

Dumairy, 1997, Perekonomian Indonesia, Penerbit : Erlangga, Jakarta.

Fayol, H. 1985. Industri dan Manajemen Umum, Terj. Winardi, London: Sir Issac and Son.

Hadi, I. 2007. Mengenal Administrasi Perpajakan di Indonesia. Bandar Lampung: Universitas Lampung.

Indiahono, D. 2009. Kebijakan Publik Berbasis Dynamic Policy Analisys. Yogyakarta: Gava Media.

Lestari,V. 2014. Analisis Pengaruh Pengalihan Pajak Bumi Dan Bangunan Pedesaan Dan Perkotaan (Pbb P2) Terhadap Penerimaan Pendapatan Daerah Kota Kediri Tahun 2012 Dan 2013. Laporan Penelitian: Universitas Negeri Surabaya.

Mansury, R., 2002, Pajak Penghasilan Lanjutan Pasca Reformasi 2000, Yayasan Pengembangan dan Penyebaran Pengetahuan Perpajakan, Jakarta 
Mardiasmo. 2012. Perpajakan.Edisi Revisi.Cetakan Ketujuh Belas.Yogyakarta: Andi

Meliala, Tulis dan Fransisca Widianti Oetomo. 2010.Perpajakan dan Akuntansi Pajak. Jakarta: Semesta Media.

Moekijat. 2003. Manajemen Kepegawaian. Penerbit PT. Bumi Aksara. Jakarta.

Moleong (1998), Metodologi Penelitian Kualitatif, CV. Remaja Rosdakarya, Bandung.

Moleong 2014, Metode Penelitian Kualitatif. Penerbit PT Remaja Rosdakarya, Bandung.

Muindro Renyowijoyo. 2008. Akuntansi Sektor Publik: Organisasi Non Laba. Jakarta: Mitra Wacana Media.

Mukhlis, I. 2010. Peran Pajak Daerah dalam Meningkatkan Pendapatan Asli Daerah. Malang: Fakultas Ekonomi Univesitas Negeri Malang.

Pasolong. H. 2011, Teori Administrasi Publik, Bandung: ALFABETA.

Rahmawan, E. 2012. Optimalisasi Pemungutan Pajak Bumi Dan Bangunan (Pbb) Dalam Peningkatan Pendapatan Daerah (Studi Pemungutan Pajak Bumi Dan Bangunan (Pbb) Di Kecamatan Limpasu Kabupaten Hulu Sungai Tengah). Jurnal Ilmu Politik dan Pemerintahan Lokal. Volume I Edisi 2. Hal 23-39.

Nugroho, R. 2011. Public Policy. Jakarta: Elex Media Komputindo.

Ridwan. 2013. Skala Pengukuran Variabel variable Penelitian. Bandung: ALFABETA.

Robbins, Stephen P. dan Timothy A. Judge. 2008. Perilaku Organisasi Edisi ke-12, Jakarta: Salemba Empat.

Saputri, E., Abdul H., dan Irwan,N .2015. Implementasi Kebijakan Pemungutan Pbb P2 Di Kecamatan Galis Kabupaten Pamekasan. Jurnal Ilmu Sosial dan Ilmu Politik. Vol 4 No 3. Hal 432-442.

Sidik, H. 1996. Pajak dan Retribusi Peranan dan Permasalahan. Bahan Kuliah Pada Sekolah Staf dan Komando TNI AL. Jakarta.

Sintaningrum, dkk. 2011. Transformasi Administrasi Negara: Perspektif Politik dan Kebijakan Publik. Jakarta: Falsafa

Soemarso, S.R, 2007, Perpajakan Pendekatan Komprehensif, Penerbit : Salemba Empat, Jakarta.

Sulistio, Eko Budi. 2007. Diktat Kuliah Pengantar Kebijakan Publik. Bandar Lampung: Universitas Lampung

Sofyan, Taufan. M, 2005, Pengaruh Penerapan Sistem Adminitarasi Perpajakan Modern Terhadap Kepatuhan Wajib Pajak Pada Kantor Pelayanan Pajak di Lingkungan Kantor Wilayah Direktorat Jenderal Pajak Wajib Pajak Besar. Skripsi Sarjana Sekolah Tinggi Akuntansi Negara. 
Soparmoko.2008. Keuangan Negara Dalam Teori dan Praktek. Penerbit : BPFEYogyakarta.

Suandy, Early, 2006, Perpajakan, Pembahasan PPh Pasal 21 Sesuai PTKP, edisi kedua, Penerbit : Salemba Empat, Jakarta.

Sukrisno, A. 2010. Akuntansi Perpajakan.Edisi Kedua Revisi. Jakarta: Salemba Empat.

Supramono dan Damayanti T.W, 2010, Perpajakan Indonesia-Mekanisme dan Perhitungan, edisi satu, Penerbit : Andi, Yogyakarta.

Samiaji,S. 2012. Penelitian Kualitatif. Jakarta. PT. Indeks.

Sugiyono. 2009. Metode Penelitian Administrasi. R\&D.Bandung. Alphabeta.

Sugiyono. 2014. Memahami Penelitian Kualitatif. Bandung : Alphabeta.

Terry, G.R., dan Leslie W. Rue. 2013. Dasar-Dasar Manajemen. Cetakan Keempat belas. Jakarta : Bumi Aksara

Tjandra, W. Riawan. 2006. Hukum Keuangan Negara, Jakarta: PT. Grasindo

Utiarahman,N.R .,Een N. Walewangko.,Hanly F. Dj. Siwu . 2016. Analisis Efektivitas Dan Kontribusi Penerimaan Pajak Bumi Dan Bangunan Perdesaan Perkotaan (Pbb-P2) Terhadap Pendapatan Asli Daerah (PAD) Kota Tomohon. Jurnal Berkala Ilmiah Efisiensi. Vol. 16 No. 02. Hal 267-277.

Wahab, Solichin Abdul. 2008. Analisis Kebijaksanaan dari Formulasi ke Implementasi Kebijaksanaan Negara. Jakarta: PT.Bumi Aksara

Waluyo. 2010. Perpajakan Indonesia.Buku Satu. Edisi Kesembilan.Jakarta: Salemba Empat.

Widjaja, HAW. 2002. Otonomi Daerah dan Daerah Otonom. Jakarta: PT Raja Grafindo Perkasa.

Winarno, Budi. 2012. Kebijakan Publik: Teori, Proses dan Studi Kasus. Yogyakarta: CAPS.

Yeremias. T. Keban. 2008 Enam Dimensi Strategis Administrasi Publik. Konsep, Teori Dan Isu. Yogyakarta: Gava Media, .

Peraturan Perundang-undangan

Undang-Undang No. 33 Tahun 2004 tentang Perimbangan Keuangan antara Pemerintahan Pusat dan Daerah. 